\title{
Philosophy of God in The View of Philosophers
}

\author{
Zaprulkhan \\ Fakultas Dakwah \\ IAIN Syaikh Abdurrahman Siddik Bangka, Indonesia \\ zaprulkhan_zahra@yahoo.co.id
}

\begin{abstract}
In every episode of human history, every human being must need God. There is no one who is not godless, even though they worship God according to their respective perceptions of God himself. According to historians, human devotion to God, the Creator is something that is both essential and existential needs of every human being. This fact can be seen also in the historical-sociological intellectual exploration conducted by Karen Armstrong about the search for humanity against God. From classical times to modern times, in Armstrong's search it turns out that every human being always constructs the concept of God. It is done by theologians, philosophers, Sufis, or reformers. Therefore, this article will explore the existence of God in the perspectives of philosophers which includes ontological arguments, cosmological arguments, teleological arguments, moral arguments, and arguments of religious experience.
\end{abstract}

Keywords : Philosophy, God, Philosopher

\section{A. Introduction}

"It is possible for you to find cities that do not have palaces, kings, wealth, ethics and venues. However, no one can find a city that does not have worship or a city that does not teach worship to its inhabitants". ${ }^{1}$

The statement was revealed by a prominent Greek historian, named Plutarch, nearly two thousand years ago. In Plutarch's expression contained an explicit message that human devotion to God, the Creator is something that is essential as well as an existential need of every human being. This fact can be seen also in the historical-sociological intellectual exploration conducted by Karen Armstrong about the search for humanity against God. From classical times to modern times, in Armstrong's search it turns out that 1998), p. 19.

${ }^{1}$ Ahmad Bahjat, Mengenal Allah, Terj. M. Abdul Ghoffar, (Bandung: Pustaka Hidayah, 
every human being always constructs the concept of God, be it lay people, theologians, philosophers, Sufis, or reformers. ${ }^{2}$

Even in his latest work, The Case for God, Karen Armstrong paints impressively about the human search for the existence of God from the era of thirty thousand years BC to the contemporary era today. ${ }^{3}$ One philosophical construction of the existence of God was carried out by philosophers. Therefore, this chapter will explore the existence of God in the perspective of philosophers which includes ontological arguments, cosmological arguments, teleological arguments, moral arguments, and arguments of religious experience.

\section{B. Ontological Arguments}

The person who first described the ontological argument was Anselm of Canterbury (1033-1109), a Benedictine who later became Archbishop of Canterbury in England. The ontological argument is entirely a priori. That is, in discussions about the existence of God, the ontological argument does not depart from empirical facts to show the existence of God; but rather depart from how we define God in us. Anselm defines God as the greatest conceivable being, the greatest conceivable being. ${ }^{4}$

Anselm understands God as "Something greater than he cannot think of" (aliquid quo maiusnogilcogitaripotest). In other words, for Anselm God is the highest that humans can think of. As high, as far as, and as deep as any human thinking ability, God is the highest, farthest, and deepest of everything that humans can think of.

If God is "something greater than he cannot think of," then logically we must be able to think of something greater than God. Because, if we are able to think of something greater than God, God - as "something greater than he cannot be thought of" - remains the greatest of the other things we can still think of.

There are two questions that immediately arise, namely: 1) Does the God we understand in such a way exist?; and 2) If "Yes", is it real or only in thought or is it similar to illusion? To question 1), Anselm said: "A fool denies it, saying in his heart: nothing", but if he hears the statement "God is something greater than he cannot think of", he grasps

\footnotetext{
${ }^{2}$ See Karen Armstrong, A History of God, ((London: Vintage Books, 1999).

${ }^{3}$ See Karen Armstrong, The Case for God, (London: The Bodley Head, 2009).

${ }^{4}$ Simon Petrus L. Tjahjadi, Tuhan Para Filsuf dan Ilmuwan, (Yogyakarta: Kanisius, 2007), p. 25-27. Definisi Tuhan: a being than which nothing greater can be conceived". Manuel Velaquez, Philosophy, (New York: Wadsworth Publishing Company, 1999), p. 276.
} 
a meaning from these words, he understood, he thought of the object that the words meant: the object was in his mind, even if he thought it did not exist. Now, the fact that such a God can be understood, thought about, yes maybe even refuted, shows that God exists, at least in thought.

But, this is question 2) is God thus only in the mind? Anselm said, "Actually, if something does not exist except in the mind, one can also think that something is also present in reality: this is a higher level." That is, if people think of something, then "something" is certainly also out of the mind or thought, that is, in reality. Because if this is not the case, the thought has no object, and a thought without an object (whatever the shape of the object) is absolutely impossible. A thought must assume the existence of a real object outside the thought itself. If I think of a white dove, for example, then that white dove is also outside of my mind, that is, in reality. Likewise, if the notion of God as "something greater than him cannot be thought of" is in the mind, then it must also be accepted that $\mathrm{He}$ is also outside of thought, namely in reality. Of course, the existence of God here should not be understood empirically, as we understand the existence of a dove in reality. ${ }^{5}$

Furthermore, in Anselm's paradigm, something that exists (is real) is certainly more perfect or more complete than something that does not exist (non-existent or not real). At this point, the perfect form that can be imagined (God) by us must be truly existent, because if it does not (exist), he (God) will become imperfect. ${ }^{6}$ The ontological argument offered by Anselm since Anselm's era is still alive until today invites debate and not a few who criticize it.

One of the sharpest criticisms of the ontological argument is that something that is thought is not necessarily really real in reality. In principle, from thinking about something, conclusions can never be drawn to the real existence of a thought. From the analysis of a concept it is never known whether what is marked by the concept actually exists or not. So that we can think of "something that cannot be thought of something

${ }^{5}$ Karen Amstrong, The Great Transformation: Awal Sejarah Tuhan. Terj. Yuliani Liputo. (Bandung: Mizan, 2006), p. 273.

${ }^{6}$ Franz Magnis-Suseno, Menalar Tuhan, (Yogyakarta: Kanisius, 2006), p. 127. 
greater than" does not mean that "something that cannot be thought of something greater than" actually exists. ${ }^{7}$

We can think abstractly of a high mountain made of gold or a palace of gold, but that does not mean that a mountain of gold or a palace of gold really exists. "You can imagine having \$ 100 (one hundred dollars), but unfortunately that shadow will not make that money a reality in your pocket," commented the British theologian John Macquarrie. ${ }^{8}$

But the ontological argument constructed by Anselm is actually not as simple as it seems, because many philosophers and thinkers agree with the concept. First, according to Franz Magnis-Suseno, if there are big thinkers who consider the ontological proof valid, there must be something in the proof that we have not touched. They are certainly not so ignorant that they do not know that it is impossible to draw conclusions from an idea to the existence of the real object that was conceived. It seems that ontological arguments can also be read in other ways. A concept is not just an abstract content or understanding that can be defined. But he is also an attempt to understand something. In this sense the concept, inadequately, expresses what is in reality. Louis Leahy mentioned the concept of as an idea.

We can also ask: How did humans come to form ideas like that? What experience did he want to reveal, expressed with concept? "Something that has no basis at all in experience, also can not be thought of". If we can form an understanding of "Something that cannot be thought of something greater than", then we must have an experience, in one form, about what is expressed in that understanding. But if there is experience, then there is also something. Experience is different from thinking. Thought is our activity. Thinking about a golden palace does not mean that a golden palace exists. But how can we think of a golden palace, if we have never seen, so experienced, something like a palace and something like gold?

But in the world of our experience which is sensed by there is no "Something that cannot be thought of something greater than" or "something that is infinite". If we form such an understanding, what is the underlying experience? Apparently humans have an experience of infinity which then pushes them to formulate that experience in the abstract concept of a "being who cannot think of anything greater than". So there is an element of

\footnotetext{
${ }^{7}$ Karen Amstrong, The Great Transformation...., p. 273.

${ }^{8}$ Franz Magnis-Suseno, Menalar Tuhan...., p. 129-130.
} 
experience. And if there is experience, then there must be something that is not only we think about, but that is outside our mind, which is facing us. That is the basic idea of those who can accept Anselm's ontological proof. ${ }^{9}$

Furthermore, in the perspective of Karen Armstrong, what should be considered more in Anselm's ontological argument is that Anselm departed from faith to understanding rather than from understanding to faith. Anselm's ontological argument emphasizes the approach of the heart (faith) rather than reason. This fact can be seen in the excerpt of his prayer which represents the core of Anselm's ontological argument:

"Lord, I am not trying to rise to your heights, because my understanding is not at all worth it. I just want to understand a little of Your truth, to which my heart is loyal and loves it (quem credit et very cormeum). Because I am not trying to understand, so that I can have faith (intellegere ut credam), but I offer myself so that I can understand (credo utintelligam); and moreover, I am convinced that if I do not offer myself, then I will not understand ". 10

In Karen Armstrong's observations, Anselm still uses the verb credere in its original meaning: it is a matter of "the heart", the center of the human self, not a purely rational act and, like Augustine, inseparable from love. Because the word "believe" has changed meaning since Anselm's time, it is wrong to translate, as is often done, credo utintelligam, as: "I believe so that I can understand". This gives the impression that before one can have any understanding of faithfulness and faith, one must first force his mind to blindly accept a number of incomprehensible doctrines. Anselm said something very different: "I involve myself so that I can understand". Anselm tried to let go of his laziness to pray by involving all his abilities, and was convinced that "If I did not involve my whole self, I would not understand". So, to spark the interest of his readers, he invited him to consider the so-called "ontological evidence" for the existence of God. ${ }^{11}$

\section{Cosmological Arguments}

\footnotetext{
${ }^{9}$ Karen Amstrong, Masa Depan Tuhan. Terj. Yuliani Liputo. (Bandung: Mizan, 2011), p. 236.

${ }^{10}$ Ibid,. p. 273.

11 Titus, Persoalan ...., p. 454.
} 
The central idea contained in the cosmological argument is the existence of a series of causal laws in the universe which must end in the first cause called God. ${ }^{12}$ However, cosmological arguments can be described as arguments about the existence of God based on the nature of the universe that is predicated and depends on something other than itself; which is based on the contingencies of the universe and its dependence on what is necessary (God).

God moves himself, while the universe has the motion given to it. God is eternal, while the universe had a beginning in time. God is actual to himself, while the universe is in a state of potential that is actualized in part in time. God cannot be changed, while the universe is in constant change. In other words, cosmologists start from an analysis of the existence of things to the existence of God and to one or more of God's attributes. ${ }^{13}$

The cosmological argument was first rolled out by Aristotle by identifying God as The Unmoved Mover $^{14}$. In subsequent developments, cosmological arguments were elaborated by some Muslim philosophers, such as Al-Kindi and IbnSina, as well as by renowned Christian philosophers, Thomas Aquinas. In the context of our discussion, I will present the cosmological argument from Thomas Aquinas.

First, the argument about Unmoved Movers. This first argument stems from our experience of motion or change. By following Aristotle, Thomas interprets motion or change with the potential transformation into actuality. An object cannot move unless it has the potential to move, and because this potential must be actualized, the actual thing must put the object in motion. In addition, because it is impossible for the same thing to be simultaneously actual and potential (for example, something actually and potentially cannot be hot in the same thing at the same time, or I actually and potentially cannot sit in the same place simultaneously), it appears that "whatever moves, must be moved by someone else".

More than that, if the activator of something automatically moves, as happened in our experience, there must be a third mobilizer. However, an infinite setback from these

${ }^{12}$ Bagus, Kamus....., p. 75.

${ }^{13}$ Abed al-Jabiri, Takwin al-Aql al-Arabi (Beirut: Markaz Dirasat al-Wahdah al-Arabiyah, 1983), p. 27-28; Bertrand Russell, History of Western Philosophy (London: Unwin University Books, 1955), p. 180-184; Karen Armstrong, A History of God (New York: Ballantine Bokks, 1993), p. 171.

14 John K. Roth, Persoalan-Persoalan Filsafat Agama, (Yogyakarta: Pustaka Pelajar, 2003), p. 125-126. 
movers cannot be understood, and must therefore be rejected as an inadequate explanation of motion. Thus, our experience encourages us to state that there must be a first unmovable mover, known to man as God. ${ }^{15}$

Second, the law of causality which states that there cannot be an unlimited set of causes: there must be a starting point. According to Thomas Aquinas, the universe operates within the bounds of efficient causality. That is, everything that we encounter directly in the natural order is a result of a cause that has produced it. This means that in the natural order, nothing can be a cause for itself. To fulfill the requirements needed to cause himself, something must exist before himself, which is an absurdity. On the other hand, it is incomprehensible to rely on an infinite set of efficient causes within the natural order. ${ }^{16}$

Each rests on the principle that there must be a final stop in the sequence of causes. Unlimited setbacks from causes or principle causes are ruled out. In addition, the argument also relies on the idea that the last stop does not go through a sequence where one causes the other. Instead, this final stop must be outside the chain and have different characteristics from the circuit. At this point, a final foundation is needed, and therefore there must be a first efficient cause, which is again known to man as God. God stands as the final and permanent source for all the cause and effect relationships that we know of. ${ }^{17}$

We can simplify this second argument in the outline of the following points:

Everything has a cause;

* Nothing is a cause for itself;

There are no endless causes;

Therefore there must be a first cause that has no cause for its existence;

* That is God as the First Cause for everything;

Therefore, God exists. ${ }^{18}$

Third, the dependent nature of every being's existence which requires the existence of a mandatory form. This third argument centers on the nature of existence itself and uses a distinction between leaning and fixed existence. In the natural order, we see that things

${ }^{15}$ Ibid., p. 127.

${ }^{16}$ Ibid..

17 Lois P. Pojman, Philosophy The Pursuit of Widom, (Amerika: Wadsworth Publishing Company, 1998), p. 74.

${ }^{18}$ John K. Roth, Persoalan-Persoalan Filsafat Agama......, p. 127-128. 
exist and are destroyed. Such objects depend. However, if we affirm that dependent existence is the only type of existence, we find ourselves in trouble.

Every existent that is dependent, and therefore can be non-existent, also has a form and therefore does not exist at any stage. Besides that, Thomas insisted that, if it were possible for everything to not exist, then at one time, nothing existed. However, if this were true, now nothing would exist, because dependent objects cannot move their own existence. But, clearly, things now exist, and this means that there must be something permanently in existence.

Furthermore, there must be a permanent form that is ultimate. This conclusion is raised by the fact that every fixed form can have a certainty (certainty) caused by another permanent form, or it may not. However, as with efficient causes, it is impossible if there is an unlimited setback of fixed forms, and therefore we are forced to acknowledge the existence of an ultimate permanent form, namely God. ${ }^{19}$

We can simplify this third argument in the outline of the following points:

Something that is possible to exist (manifest);

Every thing that is possible must have a cause for its existence;

* The cause for its existence must be something other than itself;

The cause for its existence must provide a sufficient reason for its own existence;

Therefore, what causes the existence of something that is possible must be something other than itself, something that is sufficient for its own existence;

Thus, the Absolute Essence certainly exists. ${ }^{20}$

Fourth, standing on the hierarchy of perfection that manifests in the face of the universe implies the existence of perfection that is highest above all. Everything in the universe turns out to be stratified. Some are respected, more than respected, respected. There are beautiful, more beautiful, very beautiful, and so on. The highest level is the cause of the level below it. Fire that has high heat causes low heat underneath, low heat causes heat under the nails, and so on. The Perfect One is the perfect cause, the perfect one is the imperfect cause. The top one causes the bottom one. God is supreme, he is the cause under him. ${ }^{21}$

\footnotetext{
${ }^{19}$ Joseph Runzo, Global Philosophy of Religion,......., p. 82.

${ }^{20}$ Ahmad Tafsir, Filsafat Ilmu, (Bandung: Rosda Karya, 2004), p. 92-93.

${ }^{21}$ Ibid., p. 314.
} 
But in Said Nursi's perspective, there is something that needs to be emphasized that all perfection possessed by every creature is only a relative perfection as a reflection of Absolute Perfection so that all of the relative perfection will be a shadowy shadow when compared to the perfection of the reality of the Most Perfect. ${ }^{22}$ "The innocent beauty of the" face "of the universe signifies the inevitability of the existence of the Absolute Beauty," writes Nursi. ${ }^{23}$

Fifth, the argument about the design of the universe, the order and the existence of goals so that it necessitates the existence of something that regulates the workings of the universe. This fifth argument is also called the teleological argument which we will discuss specifically below.

\section{Teleological Arguments}

For the teleological argument, I will summarize a very good explanation of the direction of the universe from Franz Magnis-Suseno in his brilliant work, Reasoning God.

Regarding this, Franz Magnis, compiled an argument in the following five steps:

1) In nature there are processes that are directed towards a goal.

2) The direction cannot be explained as a coincidence.

3) If the processes are not accidental, they are the result of direction.

4) Then the directed processes in the universe refer to the directing reality.

5) That reality is what we call God.

The basis of all this argument is the fact that in the universe there are many directed processes. It is directed in the sense that the processes appear to be organized to produce a goal, in such a way that without it the processes cannot be understood. ${ }^{24}$

Let's look at a concrete example. The universe itself is estimated to have evolved from an ancient explosion (big bang) around 14 billion years ago. According to experts, the universe is fine tuned to produce life. Fine tuned in the sense that if the physicalist properties of the universe at various stages were slightly different, it would be impossible for life to emerge. It is as if the universe, in its development, repeatedly "chooses" from the billions of possible alternatives that are available with just one alternative that ultimately

22 Said Nursi, Sinar Yang Mengungkap Sang Cahaya, terj. Sugeng Heriyanto (Jakarta: Grafindo Persada, 2003), p. 111.

${ }^{23}$ Franz Magnis-Suseno, Menalar Tuhan, (Yogyakarta: Kanisius, 2006), p. 136.

${ }^{24}$ Franz Magnis, Menalar..., p. 137-139. 
allows the formation of the realization of the planet Earth with the exact size, distance from the sun, and atmosphere to become a biological development environment which is capable of producing humans. This series of "choices" from the beginning which have a statistic almost equal to zero is also called the anthropic principle

Likewise, the formation of DNA molecules (desoxysyribo nuclein acid, basic cells of proteins): DNA molecules contain the genetic code of each animate being that ensures that embryos develop into intact organisms. According to Leahy, there are actually about 1048 possible configurations of these molecules, but only 20 of them are suitable for supporting life. So "nature" "chooses" from an almost infinite number of possibilities (a number with 48 zeros (0)) exactly the combinations that allow the growth of living organisms. ${ }^{25}$

These examples only want to pay attention to what applies to the entire natural world and presumably to the universe in general, namely that their intrinsic processes are directed. Focus on the formation of star and planetary systems, on the occurrence of life, on the evolution (phylogenesis) of increasingly complex types of organisms and on the development of each individual (ontogenesis). This direction is indeed not denied.

Thus, our argument can now be formulated as follows:

1) It is very unreasonable to understand natural processes as coincidences, and on the contrary it is very reasonable to regard them as indeed directed.

2) But if there is indeed direction, the processes refer to a directing hand.

3) Only the creator can direct the entire universe, and that is what we call God.

William Paley was one of the English theologians who initially supported the teleological argument. William Paley made a famous illustration about the clock and to strengthen the teleological argument. According to him, the universe is like a clock in which all the parts work together in harmony in an orderly manner. Anyone who sees and knows the clock, will inevitably conclude that someone intelligent has designed and made the watch. Likewise, the universe with all its complexity which is neatly arranged, accurate, and has a specific purpose, there must be an intelligent designer and maker who

\footnotetext{
${ }^{25}$ Julian Baggini, Lima Tema Utama Filsafat, terj. Nur Zaen Hai (Jakarta: Teraju, 2004), p. 165.
} 
has created it. The only thing that can be understood to describe such a creator is God Almighty and Omniscient. ${ }^{26}$

Consider this fact: To create a delicious pomegranate, when the pomegranate seed is thrown into the ground, then globally it takes at least a very harmonious cooperation between the three components: air, water and sunlight. The composition between air, water and sunlight must be precise and balanced so that it actually produces thousands of delicious pomegranate grains. The amazing creation displayed by the proportional cooperation between the three elements turns out to be seen today.

Now the critical question: How is it possible for proportional cooperation between water, air and sunlight, the three of which have no sense but are able to create delicious pomegranates, which will never be able to be created by even the most genius man until the end of time ?! If the three elements that are "dead" are capable of creating a variety of amazing works (note the various types of fruits and vegetables, and countless beautiful flowers) that are not able to be produced by humans-whoever they are-living, then isn't it natural that behind those three there is a perfect design designed by the Great Designer. As scholars say: surely there is A Designer behind the design. ${ }^{27}$ And as lay people, we all say that's God.

\section{E. Moral Arguments}

The moral argument about the existence of God was rolled out argumentatively by the great German philosopher of the 18th century, Immanuel Kant (1724-1804). ${ }^{28}$ What is the moral relationship with God? Kant has several variations of answers to this one question. Here two of Kant's famous teachings will be conveyed.

First, God and conscience. Moral awareness starts with an absolute obligation. Such binding obligations may only be imposed on humans by another person also which is absolute. That person is certainly not an ordinary human being like us, because we are limited beings. So, moral awareness in conscience presupposes the existence of a person whose commands we must obey. Now, that person is God. By acting morally and by following the conscience (practicalcheVernunft), humans acknowledge the presence of

\footnotetext{
${ }^{26}$ Joseph Runzo, Global Philosophy of Religion,......., p. 85.

27 Simon Petrus L. Tjahjadi, Tuhan Para Filsuf dan Ilmuwan (Yogyakarta: Kanisius,

${ }^{28}$ Quraish Shihab, wawasan Al-Quran (Bandung: Mizan, 1997), p. 437.
} 2007), p. 60-61. 
God. Awareness of God's presence is beyond the reach of pure theoretical thought (theoretischeVernunft). In a conscience, humans are aware of the demands of God who give and guarantee eternal law. For Kant, conscience is an awareness of an authority that absolutely binds man to his obligations, whereas God is a moral agency that gives man the absolute commandment of his conscience obligation.

Second, God and the goal of morality. For Kant, moral awareness requires us to strive for "the highest good" (summum bonum, Latin) or perfect happiness (not happiness in the empirical sense, namely: pleasure, health, wealth, or power - these are all rejected by Kant as the basis of a categorical imperative). However, the highest good or ultimate happiness, according to Kant, has never been fully realized in this world because of evil. If this is the case, there is now a problem: Are human moral actions in this world useless, because after all the ideals or goals of morality are impossible to achieve, even though that is what we must pursue?

Kant's Answer: For human moral goodness with perfect happiness to be connected, we must accept the existence of this postulate: freedom of the will, immortality of the soul, and the existence of God. It is impossible a moral obligation without freedom of will; moral law is the law in which we act on the principle that we believe in ourselves (autonomy). It is precisely because of freedom of will that we can do so! The immortality of the soul causes that human beings as moral agents can achieve the "highest good" or perfect happiness that is not possible in this world.

And finally, God is a person who guarantees that people who act well for moral obligations will experience perfect happiness. In other words, this happiness is provided by God for those who live morally good. If God is denied its existence, morality will be absurd, because the "fate" of people who live morally good will be the same as the "fate" of evil people. So, why do people still want to bother living well ?! Thus from the standpoint of this practical ratio, God is the guarantor of the absurdity of morality, and as such he is the giver of the ultimate meaning for moral life.

The three things above (freedom, immortality of the soul, and God) are called Kant postulates, which means: something that is 'serious' needs to be accepted, without needing to be proven. With the same intent Kant himself called these three posulates as "Facts of reason" (Facts der Vernunft). Meaning: the existence of the three must be accepted without hesitation (as is a 'fact'), but not as a result of empirical constellation so that it can be 
appointed with fingers, but rather as a result of the inference of practical reason over our morals.

The simplest explanation is this: virtue, the highest in the form of justice and holistic happiness can never be fully achieved in the stage of worldly life. Precisely what often happens is that reality contradicts the highest virtue, with justice, with our conscience, and happiness. Officials who committed large-scale corruption to make this nation poor, for example, have never been punished for having a high position. Some of the rulers who acted arbitrarily against the weak commoners remained happy until the end of their lives.

On the other hand, there are innumerable straight, honest and clean behavior of ordinary people whose lives are always wallowing. Likewise, not a few commoners who are just and right, and demand justice and truth, but because they clash with arrogant power and authoritarianism, they instead receive prison sentences. In the life of this world we often find facts like theatrical stage: defenders of truth, virtue, and justice are actually considered as criminals and losers, while criminals and losers with luxurious ties are considered heroes, and become respectable people.

Seeing the facts that are very contradictory to the values of this highest virtue, namely truth, happiness and justice, then the immortality of the soul, eternal life beyond death, and the existence of God the Most Just must really exist. All three, especially God the Owner of the ultimate Justice Court, must exist so that justice and happiness can be fulfilled concretely in accordance with their respective rights. At this point, for Immanuel Kant, the existence of God absolutely must exist as the final guarantor for the implementation of the ultimate virtue: absolute justice and true happiness beyond the realm of death (eternal).

\section{F. Arguments of Religious Experience}

The argument of religious experience is also called the divine experience or mystical experience that is usually experienced by mystics, Sufis, and saints (saint, mystic, Sufi). What is meant by mystical experience here is the spiritual experience, or the spirit of the wise people or Sufis when dealing with existence outside the boundaries of the material world and the real world. That experience can take the form of relationships with the nature of divine (psychology), the nature of Jabarut (spirit) and the nature of lahut (divine 
attributes). ${ }^{29}$ Sufis often claim that they have penetrated the extra-dimensional world, the supernatural transcendental world, whose existence is very different diametrically from the reality of material nature.

However, mystical experience is often claimed to be very subjective-speculative, so the nature of mystical experience is considered to have no objective-ontological basis. Actually, mystical experience is a real human experience, as sensory, mental or rational experience, and even every experience of human life, certainly has subjective and objective aspects. In this context, it is necessary to present some universal characteristics of mystical experience from various paradigms.

First, according to William James, an American philosopher and psychologist, from the perspective of the study of the psychology of religion, the fundamental characteristics of mystical experience are ineffable. The reality of malakut or the divine dimension experienced by Sufis cannot be properly described in rational language. Anyone who has experienced mystical experience will not be able to express it in words and sentences adequately. The quality of the experience must be experienced directly and cannot be told or translated to others. No one can explain precisely to others who have never experienced a particular feeling, how the nature or value of these feelings. ${ }^{30}$

Not only William James, this phenomenon is also recognized by Karen Armstrong, an observer of world religions, specifically Semitic religions (Abrahamic Religion). In Armstrong's research, someone who has experienced the initiation or revelation of the phenomenon behind the material world will not be able to put it into words. When he tried to spread the experience into words, he couldn't help but distort it. ${ }^{31}$ Huston Smith emphasized the fundamental principle; let alone factually imaginatively it cannot describe exactly how the existence of the intermediate (spiritual realm) itself. ${ }^{32}$

${ }^{29}$ It cannot be imparted or transferred to others. No one can make clear to another who has never had a certain feeling, in what the quality or worth of it consists. William James, The Varieties of Religious Experinence (New York: Topuchstone Rockefeller Gender, 1997), p. 300.

${ }^{30}$ Karen Armstrong, Menerobos Kegelapan, terj, Yuliani Liputo (Bandung: Mizan, 2004), p. $142-143$.

${ }^{31}$ Smith, Forgotten ............., p. 39.

32 Kaelan, Filsafat Bahasa Masalah dan Perkembangannya (Yogyakarta: Paradigma, 2002), p. 20-6-218. 
This has further consequences: even mystical experiences cannot be put into written form. ${ }^{33}$ In the history of Christian theology, this phenomenon has been demonstrated demonstratively by the famous medieval Christian theologian Thomas Aquinas. It is said, when Thomas Aquinas had finished dictating the final sentence of his great work, Summa Theologiae, sadly he bent his head over his arm. When his scribe asked what had happened, Aquinas replied that everything he had written seemed worthless compared to what he had witnessed. ${ }^{34}$

That is the reason why in Sufistic discourse, Sufis often pour their spiritual experiences into poetry, poetry, aphorisms or into metaphorical and allegorical language. Because these expressions, at least can represent, approach or make it easy to understand the mystical phenomena they experience. ${ }^{35}$

However, the inexplicability and inadequacy of the existence of sufficient spiritual experience does not mean that reality does not exist. Nearly seven centuries ago IbnTaimiyah revealed a philosophical rule: adamul ilmi laysa ilman bil adami. ${ }^{36}$ That is, something that can not be digested and not understood (the nature is not known) at the rational level and sentences or language, does not mean the reality of something that does not exist. It's just that mystical experiences are supramundane and even suprarasional so that they are not reachable by the capacity of the five senses and human reason.

Second, the universal characteristics of the ontological basis of objectivity for mystical experience are the orderliness and uniformity of discourses expressed by mysticists from the classical to the modern era. ${ }^{37}$ This fact is recognized by philosophers as well as modern psychologists, such as William James, R.M. Bucke, W.T. Stace, and others. In general, they have reached the conclusion that because of the regularity and uniformity of mystical experiences, it cannot be justified if mysticism is treated as a hallucination and therefore subjective.

These experts agree that with the regularity and uniformity of mystical experience, it becomes sufficient reason to view mysticism as non subjective in an important sense.

${ }^{33}$ Armstrong, A History of God..., p. 205.

${ }^{34}$ Ibn Athaillah, Al-Hikam, terj, Salm Bahreisy (Surabaya: Balai Buku, 1984). Annemarie Schimmel, Dunia Rumi, terj, Saut Pasaribu (Yogyakarta: Pustaka Sufi, 2002), p. 43-62.

${ }^{35}$ Nurcholish Madjid, Islam Agama Peradaban,(Jakarta: Paramadina, 2000), p. 202.

${ }^{36}$ See James, The Varieties..., p. 299-376.

${ }^{37}$ Mehdi Hairi Yazdi, Menghadirkan Cahaya Tuhan, terj, Ahsin Muhammad (Bandung: Mizan, 2003), p. 189-190. 
This can be analogous to an island that has never been found, which has been seen by a few people, but not yet by most people. All exposures and information provided by the few people who possess this information are characterized by regularity and uniformity. So that experience has its own valid standard of objectivity. ${ }^{38}$

The simple reason is that it is impossible for people of different times to agree to lie and produce uniform lies. In the same way, it is absurd that mystics, who are highly respected for their moral and spiritual integrity, would agree to lie and fabricate about their mystical experiences, even though their temporal and geographical distances are very far away and do not allow them to know each other or let alone make any agreement among them, including conspiracy to lie. ${ }^{39}$

Third, in fact in the study of modern psychology (after William James), the third generation of humanistic psychology by one of his most well-known figures Erich Fromm, mystical experience is considered the culmination of the development of rationality, the higgest development of rationality in which all prejudices and assumptions that still trap rational thinking are erased. To borrow the phrase Erich Fromm:

I should like to note that, quite in contrast to a popular sentiment that mysticism is an irrational type of religious experience, it represents the higgest development of rationality in religious thinking. As AlbertSchweitzerhas put it:

"Rational thinking which is free from assumptions ends in mysticism". 40

Erich Fromm's statement above led to the ontological basis of the Sufi mystical experience reaching the peak of its objectivity. Philosophically, mystical experience can be said to be a transcosmic odyssey, where one steps up a higher level of being through its deepest consciousness so as to form a complete awareness. In philosophical terms Plotinus is called a universal or total soul. ${ }^{41}$

Fourth, from a scientist-religious perspective, as demonstrated by Huston Smith, a scientist, philosopher, and contemporary religious expert, that there is another world whose existence is different from the material world. Huston Smith created a hierarchy of reality

${ }^{38}$ Kartanegara, Menyibak..., p. 72-73.

${ }^{39}$ Erich Fromm, Psychoanalysis and Religion (New Haven: Yale University Press, 1997), p. catatan no. 9, p. 93-94.

${ }^{40}$ Huston Smith, Forgotten Truth, (New York: Harper Collins, 1992), p. 48.

${ }^{41}$ Ibid., p. $34-59$ 
levels consisting of four levels: the terrestrial region or the so-called material realm (the terrestrial plane), the intermediate plane, the celestial plane, and the infinite region or divine region (the the infinite).

Of the four existences, only terrestrial regions are material in nature and the rest are immaterial or meta-empirical existences whose existence is outside the physical physical existence. However, in the study of Huston Smith, one can enter these three metaempirical regions, in addition to terrestrial material areas. ${ }^{42}$

Fifth, from the perspective of religious philosophy, in David Trueblood's view, mystical experience must at least be seen from three aspects: the morality of the people who experience it, the number of people who experience it, and changes in the quality of their wisdom. ${ }^{43}$ The subject morality standard is used as a barometer with the assumption that mystical experience cannot be measured in terms of its logical-rational qualifications, or also through exact and quantitative-empirical qualification standards. For this reason, a more universal rest is morality of the recipient of mystical experience itself.

Thus, mystical experience has a real ontological basis. Even though the experience is abstract and does not take the form of material like in the physical world, it does not mean that reality has no objective foundation. Mystical phenomena experienced by philosophers and Sufis are as real as physical nature. Consequently, mystical experiences cannot be regarded as illusions or delusions, but rather as one of the true experiences of human beings, as do other experiences both senses and mental, because they are based on the real world. It's just that the existence of mystical experience occurs at a higher level of experience (abstract) beyond sensory and rational experience. ${ }^{44}$

In the perspective of the good sages or wise men who have experienced Sufistic enlightenment, it is this mystical experience that will produce the essential beliefs about the existence of God that will never be tarnished by the seeds of faith.

\section{G. Conclusion}

Apart from all that, apart from the power of belief in approaching the existence of God that is able to surpass the power of reasoning, we must still use rational philosophical approaches in discussing God's existence. Academically, the philosophical approach is a

\footnotetext{
42 David Trueblood, Filsafat Agama, terj. Rasjidi (Jakarta: Bulan Bintang, 2002),p. 98.

${ }^{43}$ Kartanegara, Menyibak.........., p. 91.

${ }^{44}$ Karen Armstrong, A History of God..., p. 246
} 
kind of philosophical responsibility to complement our dogmatic responsibilities in religion.

As cautioned by Karen Armstrong, that excessive intellectualism will indeed damage faith, but so that God is not used as a tool to support our own selfishness, religious experience must be accompanied by an accurate assessment of its content, "Reason alone, wrote Armstrong in A History of God, "could not reach a religious understanding of reality we call 'God', but religious experience needed to be informed by the critical intelligence and discipline of philosophy if it was not to be messy, indulgent - or even dangerous emotion," So the conversation about the existence of God is ideally carried out holistically: with a belief approach through the faculty of the heart and a philosophical approach through reasoning. 


\section{BIBLIOGRAFI}

Al-Jabiri, Abed. Takwin al-Aql al-Arabi. Beirut: Markaz Dirasat al-Wahdah al-Arabiyah, 1983.

Armstrong, Karen. A History of God. London: Vintage Books, 1999.

The Great Transformation: Awal Sejarah Tuhan. Terj. Yuliani Liputo. Bandung: Mizan, 2006.

. Masa Depan Tuhan. Terj. Yuliani Liputo. Bandung: Mizan, 2011.

. A History of God. New York: Ballantine Bokks, 1993.

. Menerobos Kegelapan. Terj, Yuliani Liputo. Bandung: Mizan, 2004.

. The Case for God. London: The Bodley Head, 2009.

Athaillah, Ibn. Al-Hikam. Terj, Salm Bahreisy. Surabaya: Balai Buku, 1984.

Baggini, Julian . Lima Tema Utama Filsafat. Terj. Nur Zaen Hai. Jakarta: Teraju, 2004.

Bahjat, Ahmad. Mengenal Allah. Terj. M. Abdul Ghoffar,. Bandung: Pustaka Hidayah, 1998.

Fromm, Erich Psychoanalysis and Religion. New Haven: Yale University Press, 1997.

Kaelan, Filsafat Bahasa Masalah dan Perkembangannya. Yogyakarta: Paradigma, 2002.

Madjid, Nurcholish. Islam Agama Peradaban. Jakarta: Paramadina, 2000.

Nursi, Said. Sinar Yang Mengungkap Sang Cahaya. Terj. Sugeng Heriyanto. Jakarta: Grafindo Persada, 2003.

Pojman, Lois P. Philosophy The Pursuit of Widom. Amerika: Wadsworth Publishing Company, 1998.

Roth, John K. Persoalan-Persoalan Filsafat Agama. Yogyakarta: Pustaka Pelajar, 2003.

Runzo, Joseph . Global Philosophy of Religion. England: Oneworld Publication, 2001.

Russell, Bertrand. History of Western Philosophy. London: Unwin University Books, 1955. 
Schimmel, Annemarie. Dunia Rumi, terj, Saut Pasaribu. Yogyakarta: Pustaka Sufi, 2002.

Shihab, M. Quraish. Wawasan Al-Quran. Bandung: Mizan, 1997.

Smith, Huston. Forgotten Truth. New York: Harper Collins, 1992.

Suseno, Franz Magnis-. Menalar Tuhan. Yogyakarta: Kanisius, 2006.

Suseno. Menalar Tuhan. Yogyakarta: Kanisius, 2006.

Tafsir, Ahmad. Filsafat Ilmu. Bandung: Rosda Karya, 2004.

Tjahjadi, Simon Petrus L. Tuhan Para Filsuf dan Ilmuwan. Yogyakarta: Kanisius, 2007.

Trueblood, David. Filsafat Agama. Terj. Rasjidi. Jakarta: Bulan Bintang, 2002.

Velaquez, Manuel. Philosophy. New York: Wadsworth Publishing Company, 1999.

Yazdi, Mehdi Hairi. Menghadirkan Cahaya Tuhan. Terj, Ahsin Muhammad. Bandung:

Mizan, 2003. 